\section{Effects of Paclobutrazol Sprays on Inflorescences of Three Potted Moth Orchid Clones}

\author{
Linsey A. Newton ${ }^{1}$ and Erik S. Runkle ${ }^{2,3}$
}

Additional index words. Doritaenopsis, inflorescence elongation, Phalaenopsis, plant growth regulators, plant height, potted plants

Summary. Inflorescences of some moth orchid (Phalaenopsis and Doritaenopsis) hybrids can become very tall, which can pose shipping challenges for commercial producers and be unwieldy for consumers. We determined the efficacy of paclobutrazol as a foliar spray to inhibit inflorescence elongation of these genera and intergeneric hybrids. A single application of 15,30 , or $45 \mathrm{mg} \cdot \mathrm{L}^{-1}$ palcobutrazol at a volume of $0.2 \mathrm{~L} \cdot \mathrm{m}^{-2}$ was applied to Doritaenopsis Miss Saigon, Doritaenopsis Andrew, and Phalaenopsis 'Smart Thing' grown at $23^{\circ} \mathrm{C}$ to induce flowering. Applications were made after inflorescence emergence but before flower initiation (inflorescences were 1 to $2 \mathrm{~cm}$ long) or after flower initiation (inflorescences were 10 to $18 \mathrm{~cm}$ long). None of the paclobutrazol applications inhibited total inflorescence elongation of 'Smart Thing' or Miss Saigon. However, paclobutrazol inhibited inflorescence elongation from treatment until first flowering of Andrew by $19 \%$ to $23 \%$ when plants were treated with 15 or $45 \mathrm{mg} \cdot \mathrm{L}^{-1}$ before flower initiation and 30 or $45 \mathrm{mg} \cdot \mathrm{L}^{-1}$ after flower initiation. One or more concentrations of paclobutrazol applied after flower initiation reduced the length of the internode between the first and second flower on all three orchid clones. Paclobutrazol delayed flowering only on Miss Saigon (by 2 days) and only when applied after flower initiation. Paclobutrazol application did not affect the number of inflorescences or flowers, diameter of the first flower, number of new leaves formed, or increase in leaf span. Growers are advised to perform small-scale trials with paclobutrazol solutions starting at 30 to $45 \mathrm{mg} \cdot \mathrm{L}^{-1}$ within 1 week of inflorescence emergence, although higher concentrations may be appropriate for the most vigorous varieties. Furthermore, a late spray application can cause unwanted crowding of the flowers.

$\mathrm{P}$ lant growth retardants (PGRs) are used in commercial production of floriculture crops to inhibit plant internode elongation (Gent and McAvoy, 2000), resulting in a more aesthetically pleasing shape and reduced shipping cost due to smaller plant size. Most of the commercially available PGRs suppress internode elongation by inhibiting gibberellin biosynthesis (Gent and McAvoy, 2000). Gibberellins promote cell elongation and cell division (Taiz and Zeiger, 2006), and thus a reduction of active endogenous gibberellins by PGRs can reduce plant height.

Paclobutrazol effectively inhibits elongation of several floriculture crops, including seed impatiens (Impatiens

\footnotetext{
Department of Horticulture, Michigan State University, East Lansing, MI 48824

We gratefully acknowledge funding from growers providing support for Michigan State University floriculture research and the support from the Michigan Agricultural Experiment Station.

${ }^{1}$ Former graduate student.

${ }^{2}$ Associate Professor of Horticulture and Extension Specialist.

${ }^{3}$ Corresponding author. E-mail: runkleer@msu.edu.
}

walleriana), salvia (Salvia splendens), marigold (Tagetes erecta), petunia (Petunia $\times$ bybrida), spanish lavender (Lavandula stoechas), and chrysanthemum (Dendranthemaxgrandiflorum 'Bright Golden Anne') (Barrett and Nell, 1992; Gilbertz, 1992; Papageorgiou et al., 2002). In addition, paclobutrazol can suppress inflorescence elongation, as has been shown in lupine (Lupinus varius) (Karaguzel et al., 2004). Paclobutrazol is most effective when applied as a soil drench or sprayed on the stem (Barrett and Bartuska, 1982). In addition to application method, application timing is important in some species (Gilbertz, 1992). The concentrations appropriate for effective height control vary by species and cultivar, environmental conditions, and desired magnitude of response (Gent and McAvoy, 2000). The general recommended trial concentrations of a commercial formulation of paclobutrazol (Bonzi; Syngenta Crop Protection, Greensboro, NC) on herbaceous potted flowering plants are $30 \mathrm{mg} \cdot \mathrm{L}^{-1}$ for a spray application and $1 \mathrm{mg} \cdot \mathrm{L}^{-1}$ for a drench (Syngenta Crop Protection, 2002).

Moth orchids, which are the most common potted flowering orchids sold in the United States (Griesbach, 2002), develop inflorescences from buds on the leaf nodes of their compressed stems. Some clones have very tall inflorescences, which can pose shipping problems for commercial producers; the taller the inflorescence, the more space the plant occupies, and the greater the cost of shipping plants to their markets.

Few studies have been published on the effectiveness of PGRs on inhibiting extension of moth orchid inflorescences. In one study, application of $200 \mathrm{mg} \cdot \mathrm{L}^{-1}$ paclobutrazol to only the young inflorescence suppressed inflorescence elongation by $30 \%$ compared with that of nontreated control plants (Chyou, 1993). In a separate study, dipping entire moth orchid plants in 50 to $400 \mathrm{mg} \cdot \mathrm{L}^{-1}$ paclobutrazol or 25 to $200 \mathrm{mg} \cdot \mathrm{L}^{-1}$ uniconazole inhibited inflorescence elongation by $9 \%$ to $31 \%$ or $22 \%$ to $42 \%$, respectively, compared with that of the controls, and the higher concentrations also caused the leaves and roots to become short and thick (Wang and Hsu, 1994). Additionally, dipping plants in a PGR solution is undesirable because pathogens could be easily spread. Foliar sprays of 250 or $500 \mathrm{mg} \cdot \mathrm{L}^{-1}$ paclobutrazol reduced inflorescence length to first flower but were less effective at reducing total inflorescence length. As the length of the inflorescence at the paclobutrazol spray application increased, the inhibition of inflorescence elongation decreased (Wang and Hsu, 1994).

\begin{tabular}{llll}
\hline $\begin{array}{l}\text { Units } \\
\begin{array}{l}\text { To convert U.S. to SI, } \\
\text { multiply by }\end{array}\end{array}$ & U.S. unit & SI unit & $\begin{array}{l}\text { To convert SI to U.S., } \\
\text { multiply by }\end{array}$ \\
\hline 29.5735 & $\mathrm{fl} \mathrm{oz}$ & $\mathrm{mL}$ & 0.0338 \\
40.7458 & $\mathrm{gal} / \mathrm{ft}^{2}$ & $\mathrm{~L} \cdot \mathrm{m}^{-2}$ & 0.0245 \\
2.54 & inch $(\mathrm{es})$ & $\mathrm{cm}$ & 0.3937 \\
1 & ppm & $\mathrm{mg} \cdot \mathrm{L}^{-1}$ & 1 \\
$\left({ }^{\circ} \mathrm{F}-32\right) \div 1.8$ & ${ }^{\circ} \mathrm{F}$ & ${ }^{\circ} \mathrm{C}$ & $\left(1.8 \times{ }^{\circ} \mathrm{C}\right)+32$
\end{tabular}


The objective of this study was to quantify the effect of a single paclobutrazol spray and the timing of application on inhibiting inflorescence elongation of moth orchids.

\section{Materials and methods}

Plant material. Three moth orchid clones known to have tall inflorescences were obtained for experimentation: Miss Saigon (Doritaenopsis Orglade's Puff $\times$ Phalaenopsis Naseweis), 'Smart Thing' (parentage unknown), and Andrew (Phalaenopsis Ken Ciula $\times$ Doritaenopsis Orglade's Geos). Plants were grown in 4.5 -inch $(810 \mathrm{~mL})$ pots in a mix of $80 \%$ coarse ( 1 inch) pine bark and $20 \%$ fine coir at a commercial greenhouse in Florida. Mature vegetative plants were shipped to a commercial greenhouse in Michigan and then to Michigan State University on 19 Oct. 2007. Upon arrival, all plants were placed in a glass greenhouse at $29^{\circ} \mathrm{C}$ to prevent inflorescence initiation until the start of the experiment. The mean leaf number of Miss Saigon, 'Smart Thing', and Andrew at the beginning of the experiment was 5.8, 7.0, and 5.0 leaves, respectively.

Greenhouse environment. Plants were grown under a maximum instantaneous light intensity of 400 $\mu \mathrm{mol} \cdot \mathrm{m}^{-2} \cdot \mathrm{s}^{-1}$, maintained by a combination of shadecloth and whitewash, and a 16-h photoperiod provided by natural sunlight and high-pressure sodium lamps that provided 35 to $40 \mu \mathrm{mol} \cdot \mathrm{m}^{-2} \cdot \mathrm{s}^{-1}$ at plant canopy. Plants were fertilized at each watering with a water-soluble fertilizer dissolved in reverse-osmosis-treated water that provided the following: nitrogen, $125 \mathrm{mg} \cdot \mathrm{L}^{-1}$; phosphorus, $12 \mathrm{mg} \cdot \mathrm{L}^{-1}$; potassium, $100 \mathrm{mg} \cdot \mathrm{L}^{-1}$; calcium, $65 \mathrm{mg} \cdot \mathrm{L}^{-1}$; magnesium, $12 \mathrm{mg} \cdot \mathrm{L}^{-1}$; iron, $1.0 \mathrm{mg} \cdot \mathrm{L}^{-1}$; copper, $1.0 \mathrm{mg} \cdot \mathrm{L}^{-1}$; manganese, $0.5 \mathrm{mg} \cdot \mathrm{L}^{-1}$; zinc, 0.5 $\mathrm{mg} \cdot \mathrm{L}^{-1}$; boron, $0.3 \mathrm{mg} \cdot \mathrm{L}^{-1}$; and $\mathrm{mo}^{-}$ lybdenum, $0.1 \mathrm{mg} \cdot \mathrm{L}^{-1}$ (MSU Special; GreenCare Fertilizers, Kankakee, IL).

Plants were grown at $29^{\circ} \mathrm{C}$ until the start of the experiment on $20 \mathrm{Dec}$. 2007 , at which time they were moved to a greenhouse at $23{ }^{\circ} \mathrm{C}$ to initiate inflorescences. All temperatures were maintained with a computerized environmental system that controlled the heating system, vents, exhaust fans, and evaporative pad cooling (Priva Computers, Vineland Station, ON, Canada). Aspirated and enclosed thermocouples positioned at plant height measured the air temperature, and line quantum sensors (Apogee Instruments, Logan, UT) measured the instantaneous light intensity every 10 s. A data logger (CRI0; Campbell Scientific, Logan, UT) recorded hourly means of both temperature and light intensity. The actual mean temperature during the experiment was $23.8^{\circ} \mathrm{C}$, and the actual mean photosynthetic daily light integral at plant level was $4.6 \mathrm{~mol} \cdot \mathrm{m}^{-2} \cdot \mathrm{d}^{-1}$.

Chemical application. The concentrations of paclobutrazol used were based on a preliminary trial on Phalaenopsis 'Promis', which had shorter inflorescences than the three moth orchid clones studied in this experiment. A spray application of $30 \mathrm{mg} \cdot \mathrm{L}^{-1}$ when inflorescences were 0.3 to $7.5 \mathrm{~cm}$ tall inhibited inflorescence length of 'Promis' by $24 \%$ (data not shown).

Paclobutrazol (Piccolo; Fine Americas, Walnut Creek, CA) was applied to the moth orchid plants at one of two times at 15,30 , or $45 \mathrm{mg} \cdot \mathrm{L}^{-1}$. The two application times were before flower initiation (18 Jan. 2008, when inflorescences were 1 to $2 \mathrm{~cm}$ tall) and after flower initiation (on 4 Feb. 2008, when inflorescences were 10 to $18 \mathrm{~cm}$ tall). The paclobutrazol was applied as a foliar spray to leaves and developing inflorescences at $\approx 0.2 \mathrm{~L} \cdot \mathrm{m}^{-2}$ and no surfactant was added to the solution. Ten plants were randomly assigned to every combination of paclobutrazol concentration and application time and to the untreated control.

DATA COLLECTION AND ANALYSIS. At the start of the experiment (when plants were moved to $23{ }^{\circ} \mathrm{C}$ ), the number of leaves $(\geq 1 \mathrm{~cm}$ long) was counted. At the time of paclobutrazol application, inflorescence length (from base to apex when held straight) of treated and control plants was measured. Thereafter, inflorescence length was measured weekly until the first flower opened. Dates of the first visible inflorescence (VI) and the first open flower were recorded. When the first flower opened, inflorescence length to the first flower (from base to petiole of first flower), total inflorescence length (from base to apex when held straight), length of the internode between the first two flowers, and diameter of the first open flower were measured. In addition, the number of flowers and flower buds on each inflorescence was counted.
Weekly inflorescence length measurements were analyzed as repeated measures, with an autoregressive variance/covariance structure with heterogeneous variances. Differences were declared significant at $P \leq 0.05$. Mean separation with Tukey's honestly significant difference test at $P \leq$ 0.05 was used to analyze all flowering characteristics, vegetative growth, and final inflorescence lengths.

\section{Results}

INFLORESCENCE LENGTH. The greatest inhibitory effect of a paclobutrazol spray on inflorescence length to first flower occurred in Andrew; all three concentrations of paclobutrazol inhibited inflorescence elongation to the first flower by $\approx 20 \%$ when applied before flower initiation (Fig. 1A). The inflorescence length to first flower was also shorter than that of the control plants on Miss Saigon treated with $30 \mathrm{mg} \cdot \mathrm{L}^{-1}$ paclobutrazol before flower initiation, while plants that received a concentration of 15 or $45 \mathrm{mg} \cdot \mathrm{L}^{-1}$ were marginally shorter $(P<0.10)$. With two possible exceptions (Andrew with $45 \mathrm{mg} \cdot \mathrm{L}^{-1}$ after initiation and 'Smart Thing' with $30 \mathrm{mg} \cdot \mathrm{L}^{-1}$ before initiation), the other paclobutrazol treatments had no effect on Andrew, Miss Saigon, or 'Smart Thing'.

Total inflorescence length of all three moth orchid clones was not significantly shorter than that of the control at any point before flowering (data not shown). However, paclobutrazol inhibited inflorescence elongation of Andrew, from treatment until first flowering, by $19 \%$ to $23 \%$ when plants were treated with 15 or $45 \mathrm{mg} \cdot \mathrm{L}^{-1}$ before flower initiation and 30 or $45 \mathrm{mg} \cdot \mathrm{L}^{-1}$ after flower initiation (Fig. 2 ). Only one of the paclobutrazol applications inhibited inflorescence elongation of 'Smart Thing' or Miss Saigon at the time of the first open flower. However, if a probability value of 0.10 is used, then the application of $30 \mathrm{mg} \cdot \mathrm{L}^{-1}$ before initiation inhibited flowering of all three clones.

INFLORESCENCE INTERNODE LENGTH. The effect of paclobutrazol applications on the length of the internode between the first two flowers varied by clone (Fig. 1B). After flower initiation, paclobutrazol at 30 and 45 $\mathrm{mg} \cdot \mathrm{L}^{-1}$ applied to Andrew caused this internode to be $\approx 20 \%(7 \mathrm{~cm})$ shorter than that of the control, which was noticeable as crowding of the flowers. 


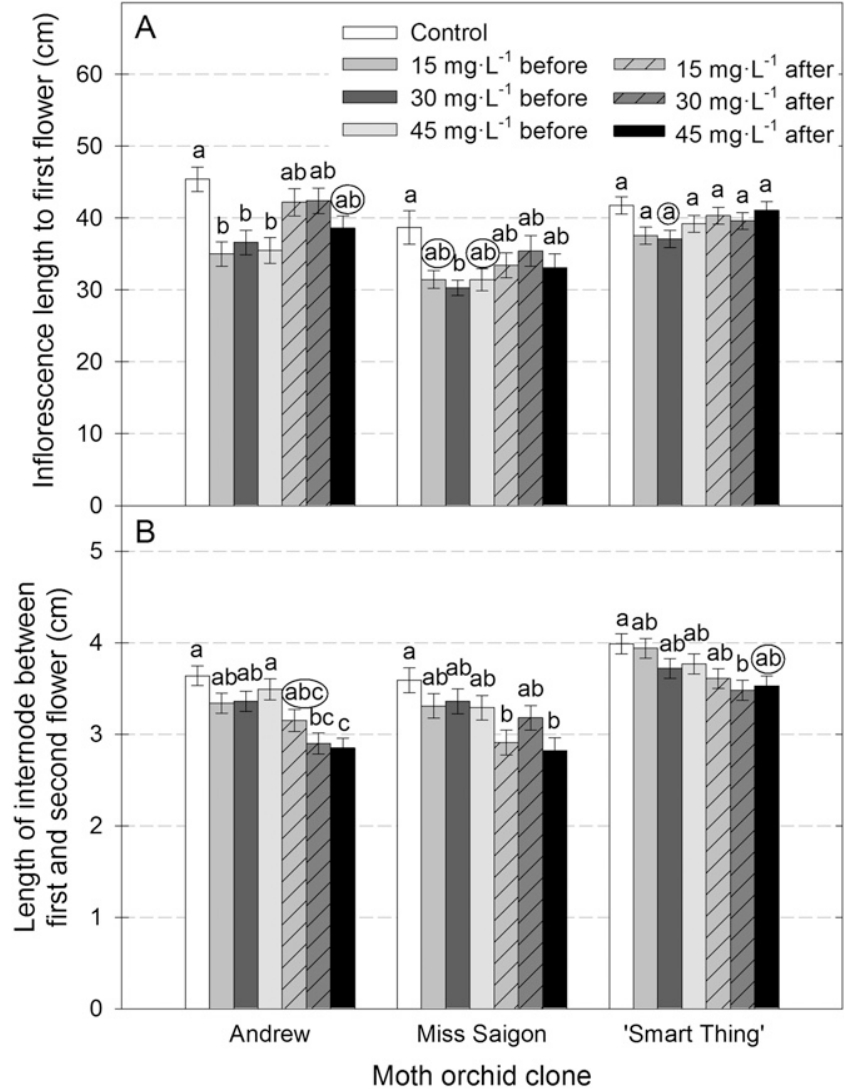

Fig. 1. Effects of paclobutrazol concentration and application time (before or after flower initiation) on inflorescence length to first flower (A) and length of the internode between the first and second flower (B) for three moth orchid clones. Error bars represent SE. Means $(n=10$ plants) within clone with the same letter are not significantly different by Tukey's honestly significant difference test at $P \leq 0.05$. Circled letters indicate means are significantly different than control at $P<0.10$; $1 \mathrm{~cm}=0.3937 \mathrm{inch}, 1 \mathrm{mg} \cdot \mathrm{L}^{-1}=1 \mathrm{ppm}$.

On Miss Saigon, 15 and $45 \mathrm{mg} \cdot \mathrm{L}^{-1}$ paclobutrazol applied after flower initiation suppressed elongation of this same internode by a similar amount. In 'Smart Thing', $30 \mathrm{mg} \cdot \mathrm{L}^{-1}$ paclobutrazol applied after flower initiation elicited a shorter internode, while those that received $45 \mathrm{mg} \cdot \mathrm{L}^{-1}$ were marginally shorter.

Other Characteristics. Paclobutrazol applied to Miss Saigon after flower initiation increased the time between VI and first open flower by $2 \mathrm{~d}$ compared with application before flower initiation, but there was no such delay in the other two clones (data not shown). Paclobutrazol did not affect the number of inflorescences or flowers formed or the diameter of the first open flower on any of the three moth orchid clones studied (data not shown). The mean number of inflorescences, flower buds on the first VI, and flower diameter, regardless of paclobutrazol treatment, was 1.0 inflorescences, 9.2 flower buds, and $10.1 \mathrm{~cm}$, respectively, for Andrew and 1.7 inflorescences, 9.8 flower buds, and $8.9 \mathrm{~cm}$, respectively, for 'Smart Thing' (data not shown). There were no apparent adverse effects of paclobutrazol treatments on vegetative growth during the experiment. The treatments did not influence the number of new leaves formed in any of the clones studied. The mean number of new leaves for all clones combined was 0.2 (data not shown).

\section{Discussion}

At the concentrations tested, a single spray application of paclobutrazol consistently inhibited inflorescence length of one of the three moth orchid clones (Andrew). For Miss Saigon and 'Smart Thing', a $30-\mathrm{mg} \cdot \mathrm{L}^{-1}$ application before initiation elicited a marginally significant $(P<0.10)$ response. There was statistically no effect of the time of paclobutrazol application on total inflorescence height. Applications of paclobutrazol after flower initiation often decreased internode length between the first two flowers, whereas the applications before flower initiation did not.

Our spray applications were slightly more effective than those of Wang and Hsu (1994), who reported that foliar sprays of $250 \mathrm{or} 500 \mathrm{mg} \cdot \mathrm{L}^{-1}$ paclobutrazol 4 weeks after potting reduced the inflorescence length to first flower by $14 \%$ and $7 \%$, respectively, but did not reduce the total inflorescence length of the moth orchid clone tested in the first year. In the second year of their study, total inflorescence length was reduced by $15 \%$. In our study, a spray of $45 \mathrm{mg} \cdot \mathrm{L}^{-1}$ was enough to inhibit total elongation of the inflorescence of one of the three clones tested. These differences could be explained by the varying responses of clones, as seen in our study.

Wang and Hsu (1994) reported a tendency for earlier applications of paclobutrazol to inhibit inflorescence elongation more than later applications. For example, inflorescence length to the first flower was inhibited by $55 \%$ when paclobutrazol was applied before inflorescence emergence and by $22 \%$ when applied to a $5.0-\mathrm{cm}$ inflorescence. These reports are consistent with the results of our study. Research on the effects of paclobutrazol on other floriculture crops has shown similar effects of application time. For example, application of $30 \mathrm{mg} \cdot \mathrm{L}^{-1}$ paclobutrazol to chrysanthemum 'Bright Golden Anne' 4 weeks after pinching inhibited plant elongation by only $3 \%$, while application at the time of pinching inhibited plant elongation by 27\% (Gilbertz, 1992).

Our results are comparable to those of Chyou (1993), who reported a $22 \%$ decrease in inflorescence length when inflorescences were brushed with a $200 \mathrm{mg} \cdot \mathrm{L}^{-1}$ paclobutrazol solution. However, the brushing application method is more labor intensive than a foliar spray and is therefore less likely to be used by commercial orchid growers. In the same study, sprays of a similar concentration $\left(250 \mathrm{mg} \cdot \mathrm{L}^{-1}\right)$ also inhibited inflorescence elongation, but root and leaf lengths were also suppressed. The lower concentrations of paclobutrazol had no observable negative effects on vegetative growth during this experiment. However, data were recorded only during 


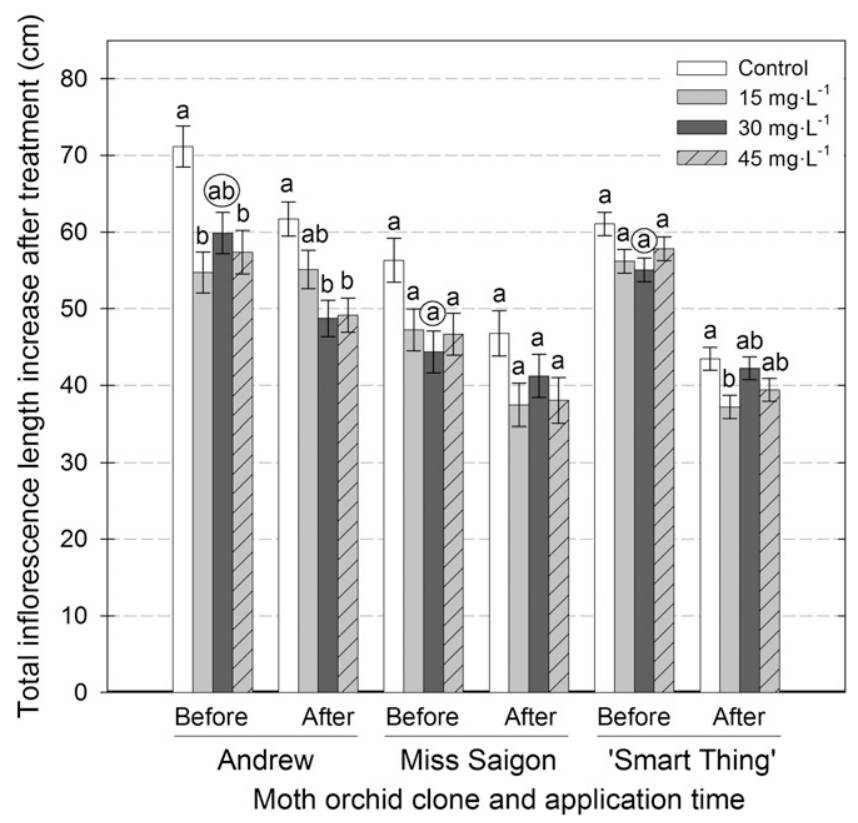

Fig. 2. Effects of paclobutrazol concentration and application time (before or after flower initiation) on increase in inflorescence length, from application time until first open flower, for three moth orchid clones. Error bars represent SE. Means $(\mathbf{n}=$ 10 plants) within clone with the same letter are not significantly different by Tukey's honestly significant difference test at $P \leq \mathbf{0 . 0 5}$. Circled letters indicate means are significantly different than control at $P<0.10 ; 1 \mathrm{~cm}=0.3937 \mathrm{inch}, 1 \mathrm{mg} \cdot \mathrm{L}^{-1}=1 \mathrm{ppm}$.

the experiment (16 to 19 weeks, depending on the clone), and an effect on vegetative growth may have become apparent if plants had been monitored for a longer period.

These results are directly applicable to growers of moth orchid who want to produce flowering plants with shorter inflorescences. According to our studies and other published work, we suggest that growers perform small-scale trials with paclobutrazol solutions starting at 30 to $45 \mathrm{mg} \cdot \mathrm{L}^{-1}$ within 1 week of inflorescence emergence (when inflorescences are $<5 \mathrm{~cm}$ tall). For some vigorous varieties, such as with Miss Saigon and 'Smart Thing', higher concentrations could be required to elicit a desirable response. Late applications should be avoided to prevent crowding of the flowers, caused by a reduction in the distance between flowers.

\section{Literature cited}

Barrett, J.E. and C.A. Bartuska. 1982. PP333 effects on stem elongation dependent on site of application. HortScience 17:737-738.

Barrett, J.E. and T.A. Nell. 1992. Efficacy of paclobutrazol and uniconazole on four bedding plant species. HortScience 27: 896-897.

Chyou, M.S. 1993. Effect of Bonzi on the flowering of Phalaenopsis. Taiwan Sugar Res. Inst. Annu. Rpt. 1992/1993:21.

Gent, M.P.N. and R.J. McAvoy. 2000. Plant growth retardants in ornamental horticulture: A critical appraisal, p. 89145. In: M.S. Basra (ed.). Plant growth regulators in agriculture and horticulture: Their role and commercial uses. Haworth Press, New York.

Gilbertz, D.A. 1992. Chrysanthemum response to timing of paclobutrazol and uniconazole sprays. HortScience 27:322323.

Griesbach, R.J. 2002. Development of Phalaenopsis orchids for the mass-market, p. 458-465. In: J. Janick and A. Whipkey (eds.). Trends in new crops and new uses. ASHS Press, Alexandria, VA.

Karaguzel, O., I. Baktir, S. Cakmakci, and V. Ortacesme. 2004. Growth and flowering responses of Lupinus varius L. to paclobutrazol. HortScience 39:1659-1663.

Papageorgiou, I., P. Giaglaras, and E. Maloupa. 2002. Effects of paclobutrazol and chlormequat on growth and flowering of lavender. HortTechnology 12:236-238

Syngenta Crop Protection. 2002. Bonzi Ornamental Growth Regulator Label. 2 Sept. 2008. <http://www.syngentap rofessionalproducts.com/pdf/labels / SCP996AL31002.pdf>.

Taiz, L. and E. Zeiger. 2006. Plant physiology, 4th ed. Sinauer Assoc., Sunderland, MA

Wang, Y.-T. and T.Y. Hsu. 1994. Flowering and growth of Phalaenopsis orchids following growth retardant applications. HortScience 29:285-288. 